\title{
Investigating Organizational Culture among Civil Servants Organizational Commitment
}

\author{
Tubagus Hkualizaman \\ Universitas Negeri Jakarta \\ Email: tubagushkualizaman_im15s3@mahasiswa.unj.ac.id \\ Hamidah \\ Universitas Negeri Jakarta \\ Email: hamidah@unj.ac.id \\ Agung Wahyu Handaru \\ Universitas Negeri Jakarta \\ Email: agung_1178@yahoo.com
}

\begin{abstract}
This study aims to explore the effects of Organizational Culture on organizational commitment of Civil Servants in an Indonesia context. The sample comprised of 71 Civil Servants working at Cilegon City Government in Indonesia which were selected by a multistage stratified sampling method. A scale that aimed to measure the Civil Servants' Organizational Culture and their organizational commitment was used to collect data. Mean scores, Pearson moment correlation coefficients, and simple linear regression analyses were carried out to analyze data. The result of this study is positive relationships between organizational culture and organizational commitment. The results indicated that organizational culture was a significant predictor of organizational commitment.
\end{abstract}

Keywords: Civil Servants, Organizational Culture, Organizational Commitment.

Received: 15 May 2019 ;

Accepted: 15 May 2019;

Publish; December 2018

How to Cite:

Hkualizaman, T., Hamidah , H., \& Handaru, A.. (2018). Investigating Organizational Culture among Civil Servants Organizational Commitment. Journal of Business and Behavioural Entrepreneurship, 2(2), 68-74.

https://doi.org/10.21009/JOBBE.002.2.03 


\section{INTRODUCTION}

Currently, human resources are the most effective important factors in the growth and improvement of organizational productivity. The topics between the commitment of the organization and the success and progress of an organization are very interesting for a more in-depth discussion (Dicky Hida Syahchari \& Kurnia, 2019). The unique nature of service to the community influences the need to conduct research that focuses on Civil Servants. Organizational commitment is an emotional attachment of individuals with organizational vision, mission, goals and values. Employees with high organizational commitment will be more enthusiastic to work and support the organization's vision, mission and goals. In addition, organizational commitment is an attribute that employees need for great loyalty and intention for a shared organization and exert more effort in their work (Hamidi et al., 2017). Employees or Civil Servants (PNS) who are committed are considered as assets for any organization. Civil servants are the most valuable assets in government organizations Civil servants have a position and play an important role because it is an element of the state apparatus tasked with carrying out development and government as an effort to achieve national goals. Usually, civil servants will remain in the organization if they have a feeling of commitment to the organization. Civil servants who are committed are motivated workforce that provides functional excellence and good performance (Rahman, Kusuma, \& Utomo, 2016).

Organizational culture as a basic philosophy that provides direction for organizational policies in the management of organizational members and a shared system of meanings is formed by its members which at the same time becomes a differentiator from one organization to another. One specific outcome of a strong culture is creating high agreement among members about what the organization believes. The harmony of objectives fosters cohesion, loyalty, organizational commitment and, most importantly, avoids conflicts (D H Syahchari, Suryasaputera, \& Yahya, 2015). But when in an embedded cultural organization environment are cultures that have negative values, then the influence that can be generated will be worrying for the development of the organization itself in the future.(Paranoan, D. B., \& Djumlani, 2017).

Several studies have shown the relationship between culture and organizational commitment. Several factors shape organizational commitment including motivation, job satisfaction and emotional intelligence. Hence, one of the important factors affecting the establishment of organizational commitment is organizational culture Organizational culture, as the most important factor affecting life and identity of an organization, has always been of particular interest to all scholars of management. Organizational culture consists of ideas, values, and attitudes that are shared by individuals in organizations; it also refers to perceptions or notions employees have toward an organization. In human-centered organizations such as service to the community, organizational culture plays an important role in creating organizational commitment and its success. To strengthen and promote the existing organizational culture in these organizations, various aspects of dominating culture available must be first examined.

Civil servants in the government of the city of Cilegon in Indonesia can play an important role in facilitating the system's objectives for the community by monitoring their culture of work and commitment, so that this research refers to the relationship between cultural organization and the commitment of Civil servants' organizations working in the government of the city of Cilegon in Indonesia is very important and this is a novelty in terms of the research object. 


\section{LITERATURE REVIEW}

\section{Organizational Commitment}

The relationship between organizational success and organizational commitment is very important to discuss. Many highly committed employees are employed and maintained by companies or organizations as an important part of their human resource management strategy. Organizational commitment in the workplace can take various forms and may be concluded, potentially affecting organizational effectiveness and employee welfare. Although there is increasing attention given to the study of organizational commitment in the workplace, it seems that there is still a lot of confusion and disagreement about it, where it is directed, how it develops, and how it affects employee behavior. Kinicki, A and Kreitner, $\mathrm{R}$ argue organizational commitment reflects how strongly someone identifies himself with an organization and is committed to its goals. This is influenced by a number of factors in the Organizing Framework, including personality, leader behavior, organizational culture, courage, organizational climate, and psychological contracts. Committed individuals tend to display two results. a) the possibility of continuing their work with their organization, b) having greater motivation to pursue organizational goals and decisions.(Kinicki, A., \& Kreitner, 2018).

Furthermore, Steven L McShane and Von Glinow said that organizational commitment represents what some experts call work attitude as a whole. Affective organizational commitment is the emotional attachment of employees to, involvement and identification with an organization. Affective commitment is a psychological bond in which a person chooses to be dedicated and responsible to the organization. Affective commitment is different from continuance commitment or continuous commitment, which is a calculative attachment to the organization (McShane, S. L., Von Glinow, M. A. Y., \& Von Glinow, 2018).

\section{Organizational Culture}

The collection of members in the organization is unique to each other. These differences come from family backgrounds, environment, education, diverse economics. This situation must be taken seriously by the organization when the organization wants to equalize perceptions and shared goals within the organization. Organizational culture will be formed with the fusion of individuals who are rich in differences that will form a different organizational culture than others.

Before stepping into the nature of organizational culture in more detail, it is better to understand what an organization is from the perspective of experts so that there is no mistake in understanding the culture as a whole. Jennifer M. George, Gareth Jones stated; The organization is a collection of people who work together and coordinate their actions to achieve various goals. The goal is what individuals try to achieve as members of an organization. In organizations there is an organizational culture that applies in it. Organizational culture can support or can also hinder the progress of the organization in achieving its goalsn (Jennifer M. George, 2012). Kinicki, A and Kreitner, $\mathrm{R}$ stated organizational culture is a set of values of mutual agreement that organizational members hold control and determine how to view, think about and react to the dynamics faced by organizations in various conditions and environments (Kinicki, A., \& Kreitner, 2018).

\section{Organizational Culture And Organizational Commitment}

Organizational culture is an important variable of employee organizational com- 
mitment. An important aspect of organizational commitment is motivating employees to be able to contribute to achieving organizational performance. Furthermore, organizational culture is an important factor in increasing the level of organizational commitment of employees. The reason why organizational culture influences employee commitment is because culture requires basic values, norms and behavior patterns that are also relevant in the organizational context. In addition, organizational culture is needed for the success or failure of an organization. In particular, positive organizational culture builds employee commitment to the organization. In addition, organizational culture can also increase employee commitment to achieving organizational goals.

The results of research by Sulakshna Dwivedi, Sanjay Kaushik, and Luxmi are employees of small-scale Outsourcing Business Process Outsourcing (BPO) companies who consider their organizational culture to be better than medium or large scale BPO (Dwivedi, Kaushik, \& Luxmi, 2013). And, with regard to organizational commitment, small-scale BPO employees have a much higher level of commitment than medium or larger BPO employees. Because organizational culture is better in smallscale BPOs and so is their commitment, the results of the research give us a signal that organizational culture has a definite impact on employee commitment. Furthermore, the results of these studies indicate that employee commitment is very sensitive to the six dimensions of organizational culture, namely Pro-action, confrontation, trust, authenticity, experimentation, and collaboration. Furthermore, the results of the study indicate that the focal point in developing any strategy must be directed at influencing employee commitment to the organization. In line with these these arguments, it is hypothesized as follows. Hypothesis 1: Organizational Culture affects significantly towards Organizational Commitment.

\section{METHODOLOGY}

This study uses a quantitative approach through survey methods with path analysis techniques (path analysis). The analysis is used to facilitate the influence or causal of exogenous variables on endogenous variables. This quantitative research approach explains statistically in answering hypothesis testing. In this cross-sectional study, 71 Civil Servants at Cilegon City Government in Indonesia were selected by a stratified sampling method.Then, different units of each class were considered as a cluster by which the study sample was randomly selected according to the list of personnel, and then the questionnaires were distributed for completion by individuals.

As for the instrument grid the variable organizational commitment and organizational culture is as follow:

Table 1 : Indicator and number of questions of organizational commitment variable

\begin{tabular}{|c|l|c|}
\hline No & \begin{tabular}{c} 
Organizational Commitment \\
\hline \multicolumn{1}{|c|}{ Indicator }
\end{tabular} & $\begin{array}{c}\text { Number of item } \\
\text { questions }\end{array}$ \\
\hline 1 & $\begin{array}{l}\text { Civil servants engagement to Cilegon City } \\
\text { Government }\end{array}$ & 9 \\
\hline 2 & $\begin{array}{l}\text { Dedication and responsibility for the target of } \\
\text { Cilegon City Government }\end{array}$ & 7 \\
\hline 3 & $\begin{array}{l}\text { Moral understanding based on the feeling of } \\
\text { obligation and responsibility in Cilegon City } \\
\text { Government }\end{array}$ & $\mathbf{2 4}$ \\
\hline
\end{tabular}

Source: Hamidi, Y., et al (2017) 
Table 2 : Indicator and number of questions of organizational culture variable

\begin{tabular}{|c|l|c|}
\hline No & \multicolumn{2}{|c|}{ Organizational Culture } \\
\hline & Indicator & $\begin{array}{l}\text { Number of item } \\
\text { questions }\end{array}$ \\
\hline 1 & Values of Life & 4 \\
\hline 2 & The stability of a conducive atmosphere & 6 \\
\hline 3 & Respect each other & 6 \\
\hline 4 & Result Orientation & 6 \\
\hline 5 & Cooperation & 6 \\
\hline & Amount & $\mathbf{2 8}$ \\
\hline
\end{tabular}

Source: Dwivedi, S., Kaushik, S., \& Luxmi. (2013)

\section{RESEARCH RESULTS AND DISCUSSION}

\section{Description of Data}

\section{Organizational Commitment}

Organizational Commitment variables have a valid number of items as many as 18 valid statements with a rating scale measurement consisting of five alternative answers (rating scale 1 to 5). The total score of Organizational Commitment is in the interval between 30 and 93 . The smallest difference in the number of scores with the largest number of scores has a range of 60 . The distribution of research data shows an average score of 61 . Other statistical values show median $=60$, mode $=56$, standard deviation $=12.68$ and variants of 160.76. The highest score in the Organizational Commitment variable is a moral understanding based on the feeling of obligation and responsibility in the Cilegon City Government while the lowest is the Civil Servants Engagement towards the Cilegon City Government

\section{Organizational culture}

Organizational culture variables have a number of valid items as many as 25 valid statements with a rating scale measurement consisting of five alternative answers (scale values 1 to 5). Number of scores Organizational culture is at intervals between 38 and 89 . The smallest difference in the number of scores with the largest number of scores has a range of 51 . The distribution of research data shows an average score of 62. Other statistical values show median $=64$, mode $=66$, standard deviation $=12.37$ and variants of 153.02. The highest score in the variable organizational culture is cooperation while the lowest value each other

Tabel 3: Result of research

\begin{tabular}{|c|c|c|c|c|c|c|}
\hline \multirow{2}{*}{ No } & \multirow{2}{*}{ Path } & \multirow{2}{*}{$\begin{array}{c}\text { Path Coeffi- } \\
\text { cient }\end{array}$} & \multirow{2}{*}{$\mathbf{T}_{\text {count }}$} & \multicolumn{2}{|c|}{$\mathbf{T}_{\text {table }}$} & \\
\cline { 5 - 7 } & & & & $\mathbf{0 , 0 5}$ & $\mathbf{0 , 0 1}$ & Result \\
\hline 1 & $\mathrm{X} 1$ to $\mathrm{Y}$ & $\mathrm{p}_{\mathrm{y} 2=0,219}$ & 2,102 & 1,997 & 2,650 & Significant \\
\hline
\end{tabular}


Many research and reference theories state that organizational culture is one of the factors that are thought to be able to influence organizational commitment. In a research written by Van Den Broek, K. F. A., Moningka, C., \& Angkawijaya in 2018 said that, "Organizational culture is important variable that could effect taxi drivers organizational commitment regardless of their generational differences" (Febrina et al., 2017). The opinion confirms that there is an influence of organizational culture on organizational commitment.

\section{CONCLUSIONS, IMPLICATIONS, AND RECOMMENDATIONS}

\section{Conclusion}

Based on the description of the analysis in this study There is a positive direct influence of organizational culture on Organizational Commitment. The findings of this study illustrate that a strong increase in organizational culture will lead to an increase in Civil Servants Organizational Commitment in Cilegon City Government.

\section{Implications}

Based on the results of the study, the following implications were formulated: The results of this study found that there was a positive direct effect of organizational culture on Civil Servants Organizational Commitments in Cilegon City Government. The implication is that the stronger the organizational culture, the higher the Organizational Commitment held by PNS in Cilegon City Government. Efforts to improve organizational culture can be done by improving the values of life, stabilizing a conducive atmosphere, mutual respect, results orientation and cooperation. Thus organizational culture is one of the important factors that must be considered to improve organizational commitment

\section{Recomendation}

Based on the conclusions and implications of the description above, the suggestions put forward by the researcher are as follows:

The organizational culture conditions should be improved because it is proven to have a positive effect on PNS Organizational motivation and Commitment in the Cilegon City Government. The weakest aspect in organizational culture is how to interpret the values of life in carrying out tasks. For this reason, improvements can be made to organizational culture, including: 1). Leaders should care about the problems that exist in employees in the context of organizational and unitary interests; 2). Leaders should be sensitive to every situation that will affect the reputation of the organization; 3 ). The unit where we work should uphold religious values, a sense of togetherness and mutual respect; 4). Strengthening organizational culture by civil servants in Cilegon City Government who have similarities in beliefs and values that are of concern to the organization.

\section{BIBILIOGRAPHY}

Dwivedi, S., Kaushik, S., \& Luxmi. (2013). Impact of organizational culture on turnover intentions in BPO sector in India. Indian Journal of Industrial Relations, 48 (4), 77-92. Retrieved from http://eds.a.ebscohost.com/eds/pdfviewer/pdfviewer? sid $=$ fd6c35a1-bccd-4775-ac5c-9c6d141ac439\%

40sessionmgr4002\&vid $=4 \&$ hid $=4105$ 
Hamidi, Y., Mohammadibakhsh, R., Soltanian, A., Behzadifar, M., Management, H., Sciences, M., \& Management, H. (2017). Relationship between organizational culture and commitment of employees in health care centers in west Iran. Electronic Physician, (January), 3646-3652.

Jennifer M. George, G. R. J. (2012). Understanding and Managing Organizational Behavior. In Pearson Hill (Sixth). https://doi.org/10.2307/30040635

Kinicki, A., \& Kreitner, R. (2018). Organizational Behavior: Key Concepts, Skills \& Best Practices.Second. McGraw-Hill/Irwin.

McShane, S. L., Von Glinow, M. A. Y., \& Von Glinow, M. A. (2018). Organizational Behavior, Emerging Knowledge Global Reality (8, ed.). McGraw-Hill Education.

Paranoan, D. B., \& Djumlani, A. (2017). Hubungan Budaya Kerja Dengan Komitmen Pegawai Negeri Sipil di Lingkungan Rumah Sakit Jiwa Daerah Atma Husada Mahakam. Jurnal Administrative Reform (JAR), 2(2), 138-148.

Rahman, M. G., Kusuma, A. R., \& Utomo, H. S. (2016). Studi Tentang Analisis Jabatan Pada Dinas Kehutanan Provinsi Kalimantan Timur. 4(4), 761-772.

Syahchari, D H, Suryasaputera, R., \& Yahya, B. A. M. (2015). Impact of Partner Fit and Conflict Management on Alliance Performance In Indonesian Construction Companies. Journal of Business and Social Review in Emerging Economies, 1(1), 17-26. https://doi.org/10.26710/jbsee.v1il.4

Syahchari, Dicky Hida, \& Kurnia, L. H. (2019). the Effect of Leadership Style and Compensation on Organizational Commitment of Babinsa in Jakarta. Jurnal Pertahanan, 4(2), 70. https://doi.org/10.33172/jp.v4i2.402 